\title{
PRODUCTION OF A CEREAL BASED PRODUCT (OGI): INFLUENCE OF CO-FERMENTATION WITH POWDERED GARLIC AND GINGER ON THE MICROBIOME
}

${ }^{*}$ Olaniran, A. F., ${ }^{2}$ Abiose, S. H., ${ }^{2}$ Adeniran, H. A., ${ }^{2}$ Gbadamosi S. O. and ${ }^{1}$ Iranloye Y. M.

1Department of Food Science and Nutrition, Landmark University, Omu-Aran, Nigeria

2Department of Food Science and Technology, Obafemi Awolowo University, Ile-Ife, Nigeria

*Corresponding Author: olaniran.abiola@lmu.edu.ng; abiolaolaniran@gmail.com

\section{ABSTRACT}

Many African foods undergo lactic acid fermentation; alterations of these germane microorganisms during fermentation of ogi can affect its acceptability as a weaning food. Effects of garlic and ginger on microorganisms' load during the production of fermented cereal (ogi) from quality protein maize were explored. Powdered garlic and ginger individually and mixed at ratio (2 and $4 \%$ ) resulted in 7 treatments. The microbial loads were enumerated, isolates identified, $\mathrm{pH}$ and total titratable acidity were also determined. Ogi with $4 \%$ garlic- $2 \%$ ginger had the lowest microbial count value $\left(19.5 \times 10^{7} \mathrm{cfu} / \mathrm{g}\right)$. Ogi containing $4 \%$ garlic- $2 \%$ ginger had the best effect on microbial loads. 4 Lactic acid bacteria were prominent while 6 yeast isolates were identified. Garlic inhibited the growth of Candida utilis, Candida mycoderma, Candida tropicalis and Candida krusei. Combination of ginger-garlic exerted better synergistic effect and addition of garlic and ginger did not affect important microorganisms involved in the fermentation of ogi.

KEYWORDS: Ogi, quality protein maize, sorghum, powdered garlic-ginger, cofermentation, microbiome 


\section{INTRODUCTION}

Cereal based foods are the main sources of cheap dietary energy in many developing countries (Greppi et al., 2013, Olaniran et al., 2019). High standards are set in the study of fermentation as a technique for the preparation of food by the World Health Organisation (WHO) food safety unit. The fermentation process for ogi production involves microorganisms and enzymes of distinct quality attributes that are quite different from the original raw materials (Solange et al., 2014). Children in most developing countries are weaned with ogi because it is cheap and readily available. Ogi is a common fermented product consumed as breakfast cereal and weaning food. It is produced from sorghum, maize and millet (Adelekan \& Oyewole, 2010, Omemu 2011, Olaniran \& Abiose, 2018). Maize is among the oldest cultivated grains worldwide; a common diet of Nigerians for centuries and it constitutes about $90 \%$ of the cereals consumed globally (Kalui et al. 2010, Omemu et al., 2018). Replacing with quality protein maize (QPM) will improve the nutritive value of consumers because it contains more lysine (30\%) and tryptophan (55\%) compared with ordinary maize (Cisse et al. 2013, Olaniran \& Abiose, 2019). About $20 \%$ increase in the linear growth of poor children weaned in communities that maize served as staple food thus contributing to food and nutrition security (Eshetie, 2017). Garlic has nutritional and medicinal values besides the broad spectrum of anti-bacterial and anti-fungal activities (Ryu \& Kang, 2017). Ginger commonly used as cooking spice due to it refreshing pleasant aroma and carminative property makes it an indispensable constituent in food processing (Olayiwola et al., 2017). Ginger and garlic are reported safe for consumption (Olaniran et al. 2015). The preparation of complementary foods that are nutritious from maize has attracted a lot of attention with several innovative approaches being adopted to improve the quality of ogi amongst other foods. This study is therefore undertaken to assess the influence of garlic and/ ginger on key microflora associated with the spontaneous fermentation of ogi produced from quality protein maize grains.

\section{MATERIALS AND METHODS Preparation of Ogi}

QPM were obtained from the Institute of Agricultural Research and Training (IAR\&T), Ibadan. Ginger rhizomes and white variety of garlic bulbs were bought in lle Ife, Nigeria. Ten (10) kilogram of quality protein maize was cleaned, steeped for $72 \mathrm{~h}$ and wet-milled into slurry using an attrition mill. Distilled water was added to form slurry without sieving (Farinde, 2015). 


\section{Preparation and Incorporation of Powdered Garlic and Ginger}

Ginger rhizomes and garlic bulbs were equally sorted for cleaning, peeled and $500 \mathrm{~g}$ of each dried for $12 \mathrm{~h}$ at $65^{\circ} \mathrm{C}$ in a Gallenkamp oven (UK) then pulverized with Marlex grinder (PVT Mumbai). The resultant powders were passed through sieve with mesh size of $50 \mu \mathrm{m}$ to get rid of shafts (Olaniran et al., 2015). The weighed ginger and garlic powder were proportion into the ogi slurry (w/w), resulting in seven treatments and one control batch and labeled in this manner: A (control samples without garlic or ginger); B (2\% garlic); C (4\% garlic); D ( $2 \%$ ginger); $\mathrm{E}$ (4\% ginger); $\mathrm{F}$ (2\% garlic-2\%ginger); G (2\% garlic- $4 \%$ ginger); $\mathrm{H}(4 \%$ garlic-2\% ginger) before fermentation. The mixtures were each evenly homogenized using glass rods and allowed to ferment for $24 \mathrm{~h}$. Aliquot samples were taken at $12 \mathrm{~h}$ interval for various analyses.

\section{Microbial Analysis}

The total viable, yeast/mould and lactic acid bacteria count were computed. Also, the microorganisms associated with ogi slurry were isolated and identified during fermentation. Dilution was carried out serially by mixing $5.0 \mathrm{~g}$ of ogi slurry with 45 $\mathrm{ml}$ of maximum recovery diluents (MRD) to obtain $10^{-1}$ dilution. The mixture was subsequently diluted serially in MRD to the preferred level of dilution. From every dilution, $1.0 \mathrm{~mL}$ was pippeted into sterilized Petri dish prior to addition of $20 \mathrm{~mL}$ each of molten Nutrient agar (NA) for Total Viable Count (TVC). To other plates; molten Man de Rogosa and Sharpe (MRS) agar was added for Lactic acid bacteria (LAB) count also PDA (Potato dextrose agar) for yeast and mould count $(0.5 \mathrm{ml}$ of $3 \mathrm{mg} / \mathrm{ml}$ Streptomycin was incorporated to inhibit bacterial growth) respectively. All plates in triplicates were incubated at $37^{\circ} \mathrm{C}$ for 24 and $72 \mathrm{~h}$ for TVC and LAB count respectively. For 3 days plates for yeast count were incubated at $28 \pm 2{ }^{\circ} \mathrm{C}$. Counting of distinct colonies using colony counter was employed for enumeration of microbial load. Colonies counted (25-250) and multiplied with the reciprocal of the dilution factor was done to obtain the count (MClandsborough, 2005).

\section{Classification and Identification of Microbes (Conventional Method)}

Repeated streaking of distinct colonies on fresh agar plates to obtain pure culture was carried out; microscopic examination and biochemical test including catalase test, oxidase test, Gram stain, sugar fermentation and production of carbon dioxide. Applicable bacteria and yeast identification scheme were employed for identification (APHA, 2015). 


\section{Determination of $\mathrm{pH}$ and Titratable Acidity}

The determination of total titratable acidity of ogi samples was measured during fermentation. Conversion factor of 0.09 was calculated as lactic acid. $\mathrm{pH}$ values of the samples were determined using Corning Scholar $425 \mathrm{pH}$ meter (Shenzhen, China). Buffer 4.0 and 7.0 was used to calibrate or standardize the $\mathrm{pH}$ meter and the electrode of the $\mathrm{pH}$ probes was sanitized with $90 \%$ ethanol prior to placing in the sample. $10 \%$ slurry of the samples was made before the determination of $\mathrm{pH}$ (AOAC, 2010).

\section{Statistical Analysis}

Calculation of means were done, separated and recorded in MS Excel sheet (2014) and Duncan Multiple Range Test (DMRT) at 5\% level of probability.

\section{RESULTS AND DISCUSSION}

The total viable counts (TVC) for all ogi samples increased throughout the fermentation period as presented in Table 1. The optimum TVC counts were recorded in the control sample $\left(95.0 \times 10^{10} \mathrm{cfu} / \mathrm{g}\right)$ while ogi containing $4 \%$ garlic$2 \%$ ginger $\left(19.5 \times 10^{7} \mathrm{cfu} / \mathrm{g}\right)$ had the lowest TVC at the end of fermentation. Although there was no observable lactic acid bacteria growth in all ogi samples at $0 \mathrm{~h}$, groups of bacteria appeared by the 12th hour and increased from 12 to 24 h. Ogi containing $4 \%$ garlic- $2 \%$ ginger had the lowest LAB count $\left(20.0 \times 10^{7} \mathrm{cfu} / \mathrm{g}\right)$ at the end of the $24 \mathrm{~h}$ fermentation. The steady increase in total viable counts and lactic acid bacteria count of ogi samples noted during the study were in agreement with previous studies by Izah et al (2016). There was no observable growth of yeast at $0 \mathrm{~h}$ of fermentation. However, the increase in yeast count was observed in all ogi treatment samples with or without garlic and ginger from 12 to $24 \mathrm{~h}$ of fermentation (Table 1). Low yeast counts were observed in all samples containing only $4 \%$ garlic; garlic-ginger at different concentrations compared with control $\left(39 \times 10^{4} \mathrm{cfu} / \mathrm{g}\right)$ at $12 \mathrm{~h}$. Similar trends were observed in all ogi samples at the end of $24 \mathrm{~h}$ fermentation. An increase in yeast count of ogi has been reported by Akinleye et al (2014). Lower microbial growth in samples containing garlic and/or ginger during fermentation can be attributed to the presence of diffusible gingerols, allicin and shogaol with antimicrobial activities as reported by Olaniran et al (2015). Its incorporation also slows down the rate of increase yeast population and there was a synergy when combined by further reducing the load with the highest impacts recorded in the combination of garlic $4 \%-2 \%$ ginger during fermentation as presented. This may have implication on the flavour and sourness at the end of fermentation while prolonging the shelf life of the product 
by reducing ropiness and development of off flavour during storage. Thus, samples containing $4 \%$ garlic- $2 \%$ ginger had the best effect on microbial counts during fermentation. Leuconostoc mensenteroides, Lactobacillus plantarum, Lactobacillus amylovorus and Lactobacillus fermentum while Saccharomyces cerevisiae, Saccharomyces rouxii, Candida utilis, Candida mycoderma, Candida tropicalis, Candida krusei were isolated. Leuconostoc mensenteroides, Lactobacillus plantarum and Lactobacillus fermentum mostly lactic acid bacteria were isolated (Tables 2). Lactic acid bacteria especially Lactobacilli were prominent in ogi during fermentation. Saccharomyces cerevisiae, Candida utilis, Candida mycoderma, Candida tropicalis were identified during fermentation from ogi (Table 3). It was also noted that the succession of these crucial isolates was not negatively affected by the integration of garlic and ginger during fermentation. Thus, garlic and ginger did not affect probiotically important microorganisms involved in the fermentation of ogi. S. cerevisiae, C. mycoderma, C. utilis and C. tropicalis have been isolated from ogi during fermentation (Greppi et al., 2013). From the finding of this study the growth of C. utilis, C. mycoderma and C. tropicalis were inhibited in all ogi samples containing garlic during the study. Garlic has been reported to have high anticandidal activity (Olaniran et al., 2015). Microbial successions during spontaneous fermentation are important. Since the overall quality of the final fermented products is connected to the populations for the transformation process attributed to the increase in lactic acid concentration caused by the activity of the LAB (Houngbédji et al., 2018). The total titratable acidity (TTA) values of all ogi samples increased during fermentation (Figures 1 and 2) while the $\mathrm{pH}$ of all ogi samples decreased throughout fermentation period (Figures 3 and 4). Fermentation of cereals has been reported to be accompanied with an increase in acidity due to the utilization of free sugars by Lactobacillus and yeast (Abioye, 2015). Adding either garlic or ginger singly or in combination to ogi slurry, improved the lactic acid bacteria flora and reduced the microbial loads during fermentation. This study has shown that garlic and ginger could be added effectively during fermentation of ogi produced either from sorghum or quality protein maize without affecting important microorganisms involved in the fermentation of ogi. Adding either garlic or ginger singly or in combination with ogi slurry, improved the lactic acid bacteria flora and reduced the microbial loads during the fermentation. Its addition of garlic and ginger during fermentation should be encouraged to eliminate unwanted microorganisms in ogi during production. 
Table 1: Microbial Load (CFU/g) of co-fermented Ogi with Garlic and Ginger

\begin{tabular}{|c|c|c|c|c|c|c|c|c|}
\hline \multirow{2}{*}{$\begin{array}{l}\text { Time } \\
\text { (h) }\end{array}$} & \multicolumn{8}{|c|}{ Samples } \\
\hline & $A$ & $B$ & C & $D$ & $E$ & $\mathrm{~F}$ & $G$ & $\mathrm{H}$ \\
\hline \multicolumn{9}{|c|}{ Total viable Count } \\
\hline 0 & $20.7 \times 10^{5}$ & $\begin{array}{l}17.7 \times 10 \\
5\end{array}$ & $\begin{array}{l}17.3 \times 10 \\
5\end{array}$ & $\begin{array}{l}18.9 \times 10 \\
5\end{array}$ & $\begin{array}{l}20.8 \times 10 \\
5\end{array}$ & $32 \times 10^{5}$ & $\begin{array}{l}10.5 \times 10 \\
5\end{array}$ & $\begin{array}{l}11.9 \times 10 \\
5\end{array}$ \\
\hline 12 & $83.0 \times 10^{7}$ & $\begin{array}{l}91.0 \times 10 \\
5\end{array}$ & $\begin{array}{l}51.0 \times 10 \\
5\end{array}$ & $36 \times 10^{5}$ & $73 \times 10^{5}$ & $77 \times 10^{5}$ & $31 \times 10^{5}$ & $28 \times 10^{5}$ \\
\hline 24 & $95 \times 10^{10}$ & $28 \times 10^{7}$ & $\begin{array}{l}22.5 \times 10 \\
7\end{array}$ & $45 \times 10^{7}$ & $42 \times 10^{7}$ & $79 \times 10^{7}$ & $82 \times 10^{7}$ & $\begin{array}{l}19.5 \times 10 \\
7\end{array}$ \\
\hline \multicolumn{9}{|c|}{ Lactic Acid Bacteria Count } \\
\hline 0 & Nil & Nil & Nil & Nil & Nil & Nil & Nil & Nil \\
\hline 12 & $35 \times 10^{7}$ & $75 \times 10^{5}$ & $65 \times 10^{5}$ & $21 \times 10^{7}$ & $\begin{array}{l}16.1 \times 10 \\
7\end{array}$ & $51 \times 10^{5}$ & $38 \times 10^{5}$ & $31 \times 10^{5}$ \\
\hline 24 & $92 \times 10^{9}$ & $57 \times 10^{7}$ & $42 \times 10^{7}$ & $\begin{array}{l}13.7 \times 10 \\
8\end{array}$ & $\begin{array}{l}12.9 \times 10 \\
8\end{array}$ & $37 \times 10^{7}$ & $29 \times 10^{7}$ & $20 \times 10^{7}$ \\
\hline & \multicolumn{8}{|c|}{ Yeast count } \\
\hline 0 & Nil & Nil & Nil & Nil & Nil & Nil & Nil & Nil \\
\hline 12 & $39 \times 10^{4}$ & $\begin{array}{l}11.3 \times 10 \\
3\end{array}$ & $79 \times 10^{2}$ & $\begin{array}{l}10.5 \times 10 \\
4\end{array}$ & $\begin{array}{l}11.7 \times 10 \\
3\end{array}$ & $28 \times 10^{2}$ & $25 \times 10^{2}$ & $22 \times 10^{2}$ \\
\hline 24 & $43 \times 10^{5}$ & $23 \times 10^{4}$ & $\begin{array}{l}18.5 \times 10 \\
4\end{array}$ & $65 \times 10^{4}$ & $30 \times 10^{4}$ & $55 \times 10^{3}$ & $72 \times 10^{3}$ & $49 \times 10^{3}$ \\
\hline
\end{tabular}

Means $(n=3)$

A (control samples without garlic or ginger); B ( $2 \%$ garlic); C (4\% garlic); D ( $2 \%$ ginger); $\mathrm{E}$ (4\% Ginger); $\mathrm{F}$ (2\% garlic-2\%ginger); G (2\%garlic-4\%ginger); $\mathrm{H}$ (4\%garlic-2\%ginger) 
Table 2: Biochemical and morphological Characteristics of bacteria isolated from co-fermented cereal with ginger and garlic

\begin{tabular}{|c|c|c|c|c|c|c|}
\hline Test & & & & Isolates & & \\
\hline & 1 & 2 & 3 & 4 & 5 & 6 \\
\hline Morphology & Rods & Rods & Cocci & Rods & Rods & Rods \\
\hline Colour of growth & Cream & Cream & Cream & Cream & Cream & Cream \\
\hline Gram reaction & + & + & + & + & + & + \\
\hline Catalase test & - & - & - & - & - & - \\
\hline Growth at: & & & & & & \\
\hline $15^{\circ} \mathrm{C}$ & + & + & & - & - & - \\
\hline $45^{\circ} \mathrm{C}$ & - & - & & + & + & + \\
\hline $\begin{array}{l}\text { Production of } \\
\qquad \mathrm{CO}_{2}\end{array}$ & - & + & + & - & + & \\
\hline $\begin{array}{c}\text { Dextran } \\
\text { production } \\
\text { fermentation of: }\end{array}$ & - & - & + & - & - & - \\
\hline Glucose & + & + & + & - & + & - \\
\hline Lactose & + & - & - & - & + & + \\
\hline Salicin & + & - & - & - & - & + \\
\hline Galactose & + & + & - & - & + & + \\
\hline Sucrose & + & + & - & + & + & + \\
\hline Raffinose & + & + & - & - & - & + \\
\hline $\begin{array}{c}\text { Probable identity } \\
\text { of organism }\end{array}$ & $\begin{array}{c}\text { Lactobacillus } \\
\text { plantarum }\end{array}$ & $\begin{array}{c}\text { Lactobacillus } \\
\text { brevis }\end{array}$ & $\begin{array}{c}\text { Leuconostoc } \\
\text { mensenteroide } \\
s\end{array}$ & $\begin{array}{c}\text { Lactobacillus } \\
\text { delbrueckii }\end{array}$ & $\begin{array}{l}\text { Lactobacillus } \\
\text { fermentum }\end{array}$ & $\begin{array}{c}\text { Lactobacillus } \\
\text { acidophilus }\end{array}$ \\
\hline
\end{tabular}

Key +: positive; -: negative 
Table 3. Biochemical and morphological Characteristics of yeast isolates from co-fermented cereal with ginger and garlic

\begin{tabular}{|c|c|c|c|c|}
\hline Test & & & Isolates & \\
\hline \multirow{2}{*}{\multicolumn{5}{|c|}{ Morphology: }} \\
\hline & & & & \\
\hline Colour & Cream & Cream & Grey & Cream \\
\hline Shape & Ovoid & Cylindrical & Cylindrical & Ovoid \\
\hline Reproduction (Budding) & Polar & Multilateral & Multilateral & Multilateral \\
\hline \multicolumn{5}{|l|}{ Fermentation: } \\
\hline Glucose & + & + & - & + \\
\hline Sucrose & + & + & - & + \\
\hline Maltose & + & - & - & + \\
\hline Galactose & + & - & - & + \\
\hline Raffinose & + & + & - & - \\
\hline Lactose & - & - & - & - \\
\hline \multicolumn{5}{|l|}{ Sugar assimilation } \\
\hline Glucose & + & + & + & + \\
\hline Sucrose & + & + & - & + \\
\hline Maltose & + & + & - & + \\
\hline Galactose & + & - & - & + \\
\hline Raffinose & + & + & - & - \\
\hline Lactose & - & - & - & - \\
\hline Trehalose & - & - & - & - \\
\hline Pellicle & - & - & + & + \\
\hline Nitrate assimilation & - & + & - & - \\
\hline Vit. free s Medium & + & + & + & $+(w)$ \\
\hline $\begin{array}{l}\text { Probable identity of } \\
\text { organism }\end{array}$ & $\begin{array}{c}\text { Saccharomyces } \\
\text { Cerevisae }\end{array}$ & Candida utilis & Candida mycoderma & Candida tropicalis \\
\hline
\end{tabular}




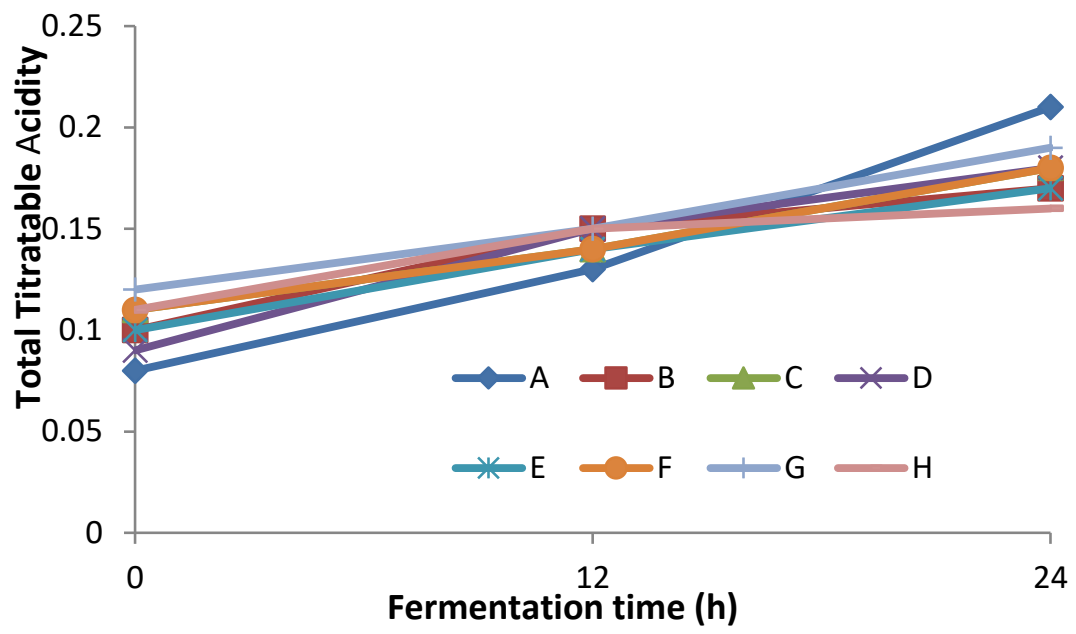

Figure 1: Total Titratable Acidity of co-fermented Ogi (maize) with Garlic and Ginger

A (control samples without garlic or ginger); B (2\% garlic); C (4\% garlic); D (2\% ginger); $\mathrm{E}$ (4\% Ginger); F (2\% garlic-2\%ginger); G (2\%garlic-4\%ginger); H (4\%garlic-2\%ginger)

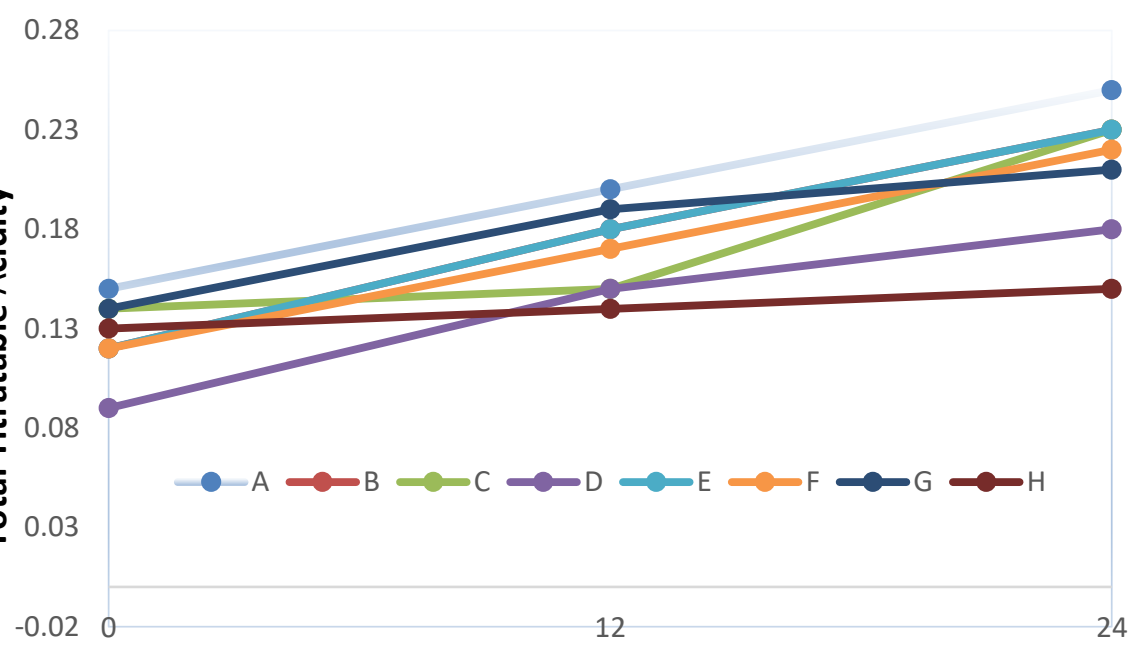

Fermentation time (h)

Figure 2: Total Titratable Acidity of co-fermented Ogi (sorghum) with Garlic and Ginger

A (control samples without garlic or ginger); B ( $2 \%$ garlic); C (4\% garlic); D ( $2 \%$ ginger); $\mathrm{E}$ (4\% Ginger); F (2\% garlic-2\%ginger); G (2\% garlic- $4 \%$ ginger); $\mathrm{H}(4 \%$ garlic- $2 \%$ ginger) 


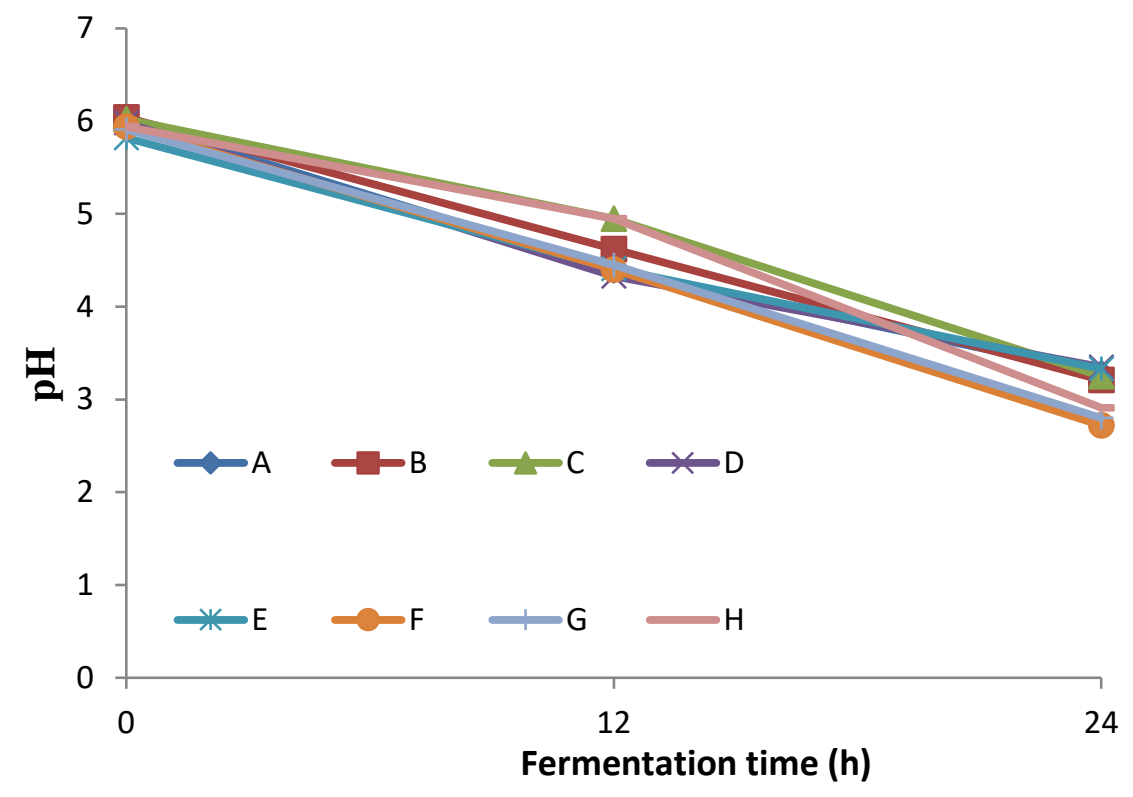

Figure 3: $\mathrm{pH}$ of co-fermented Ogi (maize)with Garlic and Ginger

A (control samples without garlic or ginger); B ( $2 \%$ garlic); C (4\% garlic); D ( $2 \%$ ginger); $\mathrm{E}$ (4\% Ginger); F (2\% garlic-2\%ginger); G (2\% garlic- $4 \%$ ginger); $\mathrm{H}$ (4\% garlic-2\% ginger)

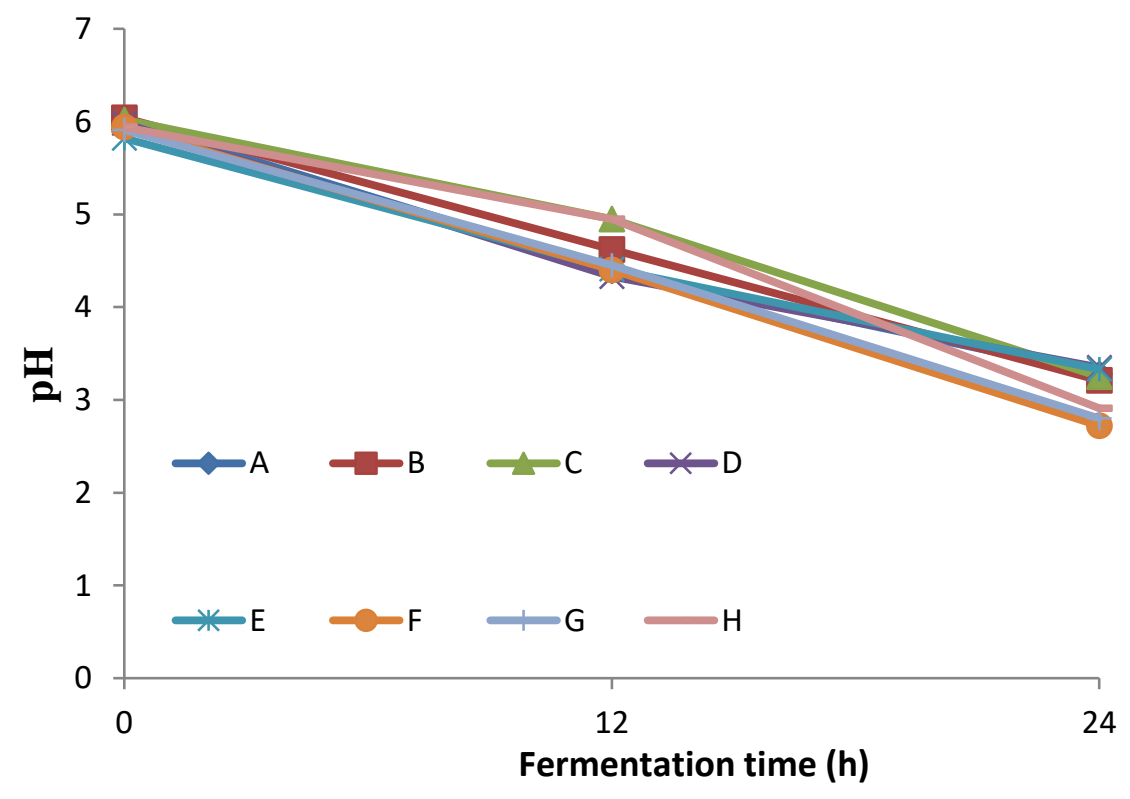

Figure 4: pH of co-fermented Ogi (sorghum) with Garlic and Ginger 
A (control samples without garlic or ginger); B ( $2 \%$ garlic); C (4\% garlic); D ( $2 \%$ ginger); E (4\% Ginger); F (2\% garlic-2\%ginger); G (2\% garlic-4\% ginger); H (4\% garlic- $2 \%$ ginger).

\section{CONCLUSION}

The microflora present during spontaneous fermentation of cereals plays a key role in the acceptability of the final product. This study shows that addition of garlic and ginger at 2 or $4 \%(\mathrm{w} / \mathrm{w})$ during fermentation of ogi produced from quality protein maize did not have a negative significant effect on the natural microflora involved in the production of ogi. Co-fermentation of the cereals with garlic, ginger, or ginger and garlic improved the lactic acid bacteria flora and reduced the microbial loads during the fermentation. Thus, its addition during fermentation is recommended to inhibit unwanted microorganisms in ogi during production.

\section{REFERENCES}

Abioye F.V. (2015). Proximate composition and sensory properties of Moringa fortified Maize-Ogi. Journal of Nutrition and Food Sciences, S12, 1-4.

Adelekan, A. O. and Oyewole, O. B. (2010). Production of Ogi from germinated sorghum supplemented with soybean. African Journal of Biotechnology, 9(42), 7114-7121

Akinleye, O. M., Fajolu, I. O., Fasure, A. K., Osanyinpeju, O. S., Aboderin, A. O. and Salami, O. O. (2014): Evaluation of micro-organisms at different stages of production of Ogi in Alimosho Community, Area Southwest, Lagos, Nigeria. American Journal of Research Communication, 2(10), 215-230.

AOAC International., William W. H and George W. L. (2010). Official methods of analysis chemistry. Gaithersburg.

American Public Health Association (APHA) (2015). Compendium of Methods for the Microbiological Examination of Foods. Fifth edition, American Public Health Association Washington, DC., USA.

Cisse, M., Zoue, L. T., Soro, Y. R., Megnanou, R. and Niamke, S. (2013). Physicochemical and functional properties of starches of two quality protein maize (QPM) grown in Côte d'Ivoire. Journal of Applied Biosciences, 66, $5130-5139$

Eshetie, T. (2017). Review of quality protein maize as food and feed: In alleviating protein deficiency in developing countries. American Journal of Food and Nutrition, 5(3), 99-105.

Farinde, E. O. (2015). Chemical and sensory properties of sieved and unsieved 
fortified Ogi. Nature and Science, 13 (1), 49-53.

Greppi A., Rantsiou K., Padonou W., Hounhouigan, J., Jespersen L., Jakobsen

M. and Cocolin, L. (2013). Determination of yeast diversity in ogi, mawè, gowé and tchoukoutou by using culture-dependent and independent methods. International Journal of Food Microbiology, 165(2), 84-88.

Izah S.C., Kigigha L.T. and Okowa I.P. (2016). Microbial quality assessment of fermented maize Ogi (a cereal product) and options for overcoming constraints in production, Biotechnological Research, 2, 81-93.

Houngbédji, M., Johansen, P., Padonou, S. W., Akissoé, N., Arneborg, N., Nielsen, D. S., Hounhouigan, D. J., and Jespersen, L. (2018). Occurrence of lactic acid bacteria and yeasts at species and strain level during spontaneous fermentation of mawè, a cereal dough produced in West Africa. Food Microbiology, 76, 267-278.

Kalui, C. M., Mathara, J. M. and Kutima, P. M. (2010). Probiotic potential of spontaneously fermented cereal based foods - A review. African Journal of Biotechnology, 9(17), 2490-2498

MClandsborough, L.A. (2005). Food Microbiology Laboratory, CRC Press, Boca Raton, FL.

Olaniran, A.F., Abiose, S.H., Adeniran, A.H. (2015). Biopreservative effect of Ginger (Zingiber Officinale) and Garlic powder (Allium Sativum) on tomato paste. Journal of Food Safety, 35(4), 440-452.

Olaniran, A.F. and Abiose, S.H. (2018). Proximate and Antioxidant activities of bio-preserved flour with garlic and ginger ogi. F1000Research,7(1936),116.

Olaniran, A.F. and Abiose, S.H. (2019). Nutritional evaluation of enhanced unsieved Ogi Paste with Garlic and Ginger. Preventive Nutrition and Food Science, 24(3), 348-356.

Olaniran, A.F., Abiose, S.H. and Gbadamosi, S.O. (2019). Quality attributes and acceptability of ogi flour biofortified with garlic and ginger. Journal of Health Science, 7, 101-109.

Olayiwola, J. O., Victoria, I., Mobolaji, A. B. (2017). Bacteriological and proximate evaluation of ginger-fortified fermented Maize (Ogi). American Journal of Food Technology, 12(6), 374-378.

Omemu, A. M. (2011). Fermentation dynamics during production of ogi, a Nigerian fermented cereal porridge. Report and Opinion, 3(4), 8-17.

Omemu, A. M., Uchechukwu, I. O., Adewale, O. O., Mobolaji, O. B., Samuel, A. O. A. (2018). Microbiological assessment of maize ogi cofermented with Pigeon Pea. Food Science and Nutrition, 6(5),1238-53. 
Ryu, J. H., Kang, D. (2017). Physicochemical properties, biological activity, health benefits, and general limitations of aged black Garlic: A Review. Molecules, 22(6), 919.

Solange, A., Konan, G., Fokou, G., Dje, K. M., Bonfoh, B. (2014). Review on African traditional cereal beverages. American Journal of Research Communication, 2(5), 103-153. 